\title{
Over standbeelden, totempalen en de herinnering aan de slavernij
}

\author{
Markus Balkenhol
}

De beelden van de confederale generaal Robert E. Lee in de Verenigde Staten, het beeld van Cecil Rhodes op de campus van de Universiteit van Cape Town en dat van Mahatma Ghandi op de campus van de Universiteit van Ghana hebben allemaal te maken gekregen met de kwestie: moeten ze verdwijnen omdat ze verwijzen naar racistische opvattingen?

In de nasleep van deze soms gewelddadige controverses is het meest gehoorde argument voor het behoud van de standbeelden dat door het verwijderen geschiedenis uitgewist zou worden. De beweegredenen voor het behoud lopen daarbij uiteen. Sommigen willen trots kunnen zijn op wat zij als 'hun' geschiedenis ervaren, anderen vinden juist dat het weghalen van de standbeelden het historisch besef in de weg staat; een manier om de geschiedenis 'wit te wassen'. Voor het verwijderen van standbeelden spreekt dat sommige mensen zich herinnerd voelen aan een pijnlijke geschiedenis van onderdrukking en slavernij, en dat standbeelden een eenzijdig, namelijk uitsluitend positief beeld van die geschiedenis zouden weergeven.

De discussies rondom (stand)beelden, zo zal ik in dit artikel betogen, laten zien dat een bredere aandacht voor kolonialisme en het slavernijverleden niet per se leidt tot meer inzicht. In toenemende mate blijkt dat het probleem niet simpelweg onkunde is, zoals bijvoorbeeld de afwezigheid van het slavernijverleden in schoolboeken. Het is niet een probleem dat met meer kennis alleen verholpen kan worden, maar het ligt dieper. 'Kennis', zo blijkt, is nooit objectief, maar wordt in belangrijke mate gevormd door het perspectief van waaruit op het verleden gekeken wordt

Beelden zijn een goede casus om dit te onderzoeken. Beelden vormen namelijk onze kijk op de wereld. In dit stuk betoog ik dat beelden een centraal element zijn in processen van groepsvorming in het heden, terwijl ze zijn gevormd door het verleden. Zo kan een ver verleden invloed hebben op maatschappelijke verhoudingen van vandaag.

* Dr. Markus Balkenhol werkt als sociaal en cultureel antropoloog aan kolonialisme, ras, burgerschap, cultureel erfgoed en religie. Zijn PhD-dissertatie gaat over het cultureel geheugen van de slavernij in Amsterdam-Zuidoost. Hij is als onderzoeker verbonden aan het Meertens Instituut. Recente artikelen van zijn hand zijn getiteld 'Zwarte Pieten, moskeebezoek en zoenende mannen. Katholiek activisme van Cultuur onder Vuur en de culturalisering van religie' en 'Iconic Objects. Making Diasporic Heritage, Blackness, and Whiteness in the Netherlands'. 


\section{Nederlandse beeldenstorm}

Net als in de Verenigde Staten, Zuid-Afrika en Ghana is in Nederland de discussie over beelden volop gaande. Controverses ontstonden over de voorgestelde naamsverandering van kunstcentrum Witte de With in Rotterdam, over de beslissing van het Mauritshuis om een buste van Maurits niet meer te exponeren, en over de tentoonstelling Goede Hoop in het Rijksmuseum over de relatie tussen Nederland en Zuid-Afrika vanaf 1600. Een van de felste controverses in dit kader had betrekking op Jan Pieterszoon Coen en de grote aanwezigheid van deze naam: een groot aantal straten, pleinen en scholen en een tunnel zijn naar hem benoemd. Daarnaast staat er over het land verdeeld een aantal standbeelden van Coen. Critici herinneren aan de moord op nagenoeg de gehele bevolking van de Banda-eilanden in 1621, die onder zijn leiding werd uitgevoerd. Tegen deze achtergrond vinden zij deze standbeelden ongepast en pijnlijk. Deze kritiek deed de vraag rijzen of dit soort standbeelden moetn verdwijnen, en of straten, scholen en pleinen van naam moeten veranderen.

Net als in het buitenland was het argument van Nederlandse voorstanders van het behoud van standbeelden en plaatsnamen dat het verwijderen ervan neerkomt op het uitwissen van de geschiedenis. Dit zou een kritische discussie over Coen juist in de weg staan. Coen zou vergeten worden en daarmee ook zijn wandaden. De discussie rondom zijn naam staat daarnaast symbool voor de grotere vraag hoe Nederland om moet gaan met het koloniale en slavernijverleden. In het kader daarvan verscheen emeritus hoogleraar Piet Emmer op woensdag 17 januari 2017 als gast bij de talkshow De Wereld Draait Door om te praten over het thema 'beeldenstorm'. Volgens Emmer moesten standbeelden van Coen niet verwijderd worden, omdat daarmee geschiedenis 'weggepoetst' zou worden:

'Laten we eerlijk zijn, op dit ogenblik zouden we geen school of tunnel of standbeeld voor Jan Pieterszoon Coen maken, en noemen. Maar, aan de andere kant, het is onderdeel van ons koloniaal verleden. Dat koloniaal verleden ging, zeker in de 17de eeuw, met veel geweld gepaard. Ik denk dat het zinloos is om voortdurend dingen die ons op dit ogenblik verkeerd voorkomen, om daar straatnamen te veranderen, beelden te veranderen. Natuurlijk, het gebeurt, denk aan, ik geloof, ISIS in het Midden-Oosten, die een hele stad van voor het Mohammedaanse tijdperk wil vernietigen, denk aan de Nazi's die alle namen met Joden wilden veranderen. Daar willen we toch niet bij horen?! Het beste is, zoals gezegd, dat we die namen laten staan, die standbeelden laten staan, en daarover praten. Ik denk dat dat de beste oplossing is.'

Emmer schetst in zijn vertoog een 'wij' met bepaalde kenmerken: rationeel, redelijk en uit op een constructief gesprek. Deze 'wij' zet hij tegenover een fanatiek, gewelddadig en irrationeel 'ander'. 'Wij' zijn beschaafd, 'zij' zijn wild. Die wildheid houdt niet alleen in dat 'zij' niet vatbaar zijn voor rede, maar ook dat zij in dingen geloven. 'Zij' denken dat de geschiedenis verandert als standbeelden verdwijnen 
en straten hernoemd worden. Zoals Emmer het uitdrukt: 'Als die mensen [sic] weggehaald worden, het verleden verander je daarmee niet.'

Dit is een vaak gehoorde kritiek over mensen die zich gekwetst voelen door standbeelden: zij nemen beelden te serieus en dichten ze haast bovennatuurlijke krachten toe. Volgens deze redenering ligt dat aan de mensen zelf, niet aan de standbeelden: zij kiezen ervoor om gekwetst te worden door een stuk steen of brons. Als je gelooft dat standbeelden dit soort dingen kunnen doen, dan ben je in feite een animist: iemand die gelooft dat dingen levendig zijn en bovennatuurlijke krachten hebben! Dat is natuurlijk onzin, vindt Emmer: 'Daar willen we toch niet bij horen?!'

\section{De kracht van beelden}

Eigenlijk gaan deze discussies dus niet alleen over het verleden, maar ook over de kracht van beelden. Geloven we in de kracht van beelden of niet? De zaak ligt complexer dan Emmer suggereert. Zeker voor een historicus is het toch enigszins opmerkelijk om te stellen dat vooral religieuze fanaten en de nazi's standbeelden en straatnamen willen veranderen. Emmer zou moeten weten dat dit de normale gang van zaken in de geschiedenis is en niet wordt beperkt tot gewelddadige regimes. Het gebeurde massaal na de Tweede Wereldoorlog in Duitsland met tal van Adolf Hitler Plätzen en Straßen, maar ook in Nederland werd een Adolf Hitler Allee weer de Kloosterweg, en werd in Amsterdam onder andere een plein weer het Jonas Daniël Meijerplein. En in het Midden-Oosten heeft niet alleen ISIS beelden neergehaald; Amerikaanse soldaten haalden, onder grote belangstelling van de media, een groot standbeeld van Saddam Hoessein neer na de inname van Bagdad aan het einde van de tweede Golfoorlog.

Emmers betoog schuurt: als 'wij' niet in de kracht van beelden geloven, waarom willen 'we' ze dan zo graag in hun huidige staat behouden? Waarom zijn sommige beelden als het ware taboe? Dat de feitelijke historische gebeurtenissen door het weghalen van een standbeeld in het geding zouden komen, kan niet de reden zijn. Een historische figuur zoals bijvoorbeeld de confederale generaal Lee, of de Nederlandse Coen, zal niet uit de geschiedenisboeken verdwijnen omdat zijn standbeeld verwijderd wordt. Er zijn boekenkasten volgeschreven over Coen en die zullen niet samen met de standbeelden verdwijnen. Andersom verdwijnt een naam zoals Anton Mussert, de grondlegger van de nationaalsocialistische beweging in Nederland, ook niet zomaar uit de geschiedenis omdat er géén standbeelden voor hem zijn. Historicus Karwan Fatah-Black, ook aanwezig in het praatprogramma, hield Emmer dan ook voor: 'Zo leren we toch geen geschiedenis? We leren toch geen geschiedenis door straatnamen te bekijken?'

\section{Wat doet een standbeeld eigenlijk?}

In het veld van de herinneringsstudies wordt vaak een scheiding aangehouden tussen geschiedschrijving aan de ene kant en herinnering aan de andere kant. Aan de ene kant de wetenschappelijke, afstandelijke en kritische houding ten opzichte 
van het verleden, en aan de andere kant de belichaamde, subjectieve en gepassioneerde ervaring van het verleden. Volgens deze definitie vallen standbeelden in de categorie 'herinnering'. Zo schrijft politicoloog Kevin Bruyneel (2017) in een recent artikel over de omgang met standbeelden:

'The argument [against the removal of statues] has, at least, one fundamental flaw. Removing monuments does not erase history because monuments are not about history. They are about memory.'

In de praktijk lopen deze categorieën doorgaans in elkaar over. Een archiefstuk kan bijvoorbeeld van grote waarde zijn voor historisch onderzoek, maar het kan ook, los van de inhoud, als historisch object gewaardeerd worden. Denk bijvoorbeeld aan de Amerikaanse onafhankelijkheidsverklaring, een belangrijke tekst voor historici en filosofen. Tegelijkertijd kan een dergelijk object als cultureel erfgoed ook een enorme aantrekkingskracht ontwikkelen. Het is, om met de woorden van de beroemde Nederlands historicus Johan Huizinga te spreken, 'een historische sensatie' om zich voor te stellen dat dit stukje papier is aangeraakt door de founding fathers.

Hoewel geschiedenis en herinnering in de praktijk niet zuiver te scheiden zijn, bestaan er toch verschillende registers waarin mensen zich tot het verleden verhouden. Kennis van het verleden is altijd een reconstructie, en dus sociaal en cultureel geconstrueerd. Bij deze reconstructie zijn bronnen of historische 'feiten' belangrijk, maar even belangrijk is het dat mensen overtuigd zijn van de feitelijkheid. Er is, met andere woorden, authenticatie nodig om een publiek, academisch of breed, van de waarheid en geloofwaardigheid van historische bronnen en de interpretatie daarvan te overtuigen (Van de Port \& Meyer, 2018). Een bron alleen zegt namelijk nog niet zoveel, het is de context waarin deze geplaatst wordt die een bron voor mensen betekenisvol maakt.

Authenticatie kan op verschillende manieren gebeuren. In de herinneringsstudies wordt met geschiedenis of geschiedschrijving over het algemeen de geformaliseerde, meestal kritische wetenschap van het verleden bedoelt. Deze richt zich op het achterhalen en interpreteren van data voor een reconstructie van het verleden. Hier werkt authenticatie volgens wetenschappelijke criteria, zoals bronvermeldingen, inbedding in bestaande wetenschappelijke literatuur, en peerreview. Ook al zijn de resultaten een sociale constructie en dus niet objectief of neutraal (Trouillot, 1995), ze zijn wel controleerbaar en dus in principe ook weerlegbaar.

Sociale, collectieve of culturele herinnering is een ander register van authenticatie. Ook hier moeten mensen van de authenticiteit of echtheid van een geschiedbeeld overtuigd raken, maar spelen wetenschappelijke criteria een minder belangrijke rol. Waar geschiedschrijving doelt op het documenteren en begrijpen van het verleden, doelt herinnering op het ervaarbaar maken ervan. Herinnering ontleent haar authenticiteit dan ook meer aan de mate waarin het verleden tastbaar gemaakt wordt, bijvoorbeeld door het tentoonstellen en toegankelijk maken van historische objecten. Het gaat erom de geschiedenis levendig te maken, dat wil zeggen: het doel is om mensen door het verleden te laten raken. In theorie zou je dus kunnen zeggen dat geschiedenis kritische, beschouwende afstand tot het ver- 
leden creëert, terwijl herinnering die afstand juist wil overbruggen en het verleden naar het heden wil brengen.

Bij standbeelden staat deze tweede dimensie op de voorgrond. Een standbeeld spreekt een bepaalde waardering van een historisch gegeven uit. Standbeelden zijn, anders dan monumenten, uitsluitend bedoeld om een persoon of een gebeurtenis uit het verleden positief te waarderen. Bepaalde aspecten kunnen uitvergroot worden, waarbij historische accuraatheid niet altijd het meest belangrijk is (Stengs, 2018). De uitdrukking 'iemand op een voetstuk zetten' refereert letterlijk en figuurlijk aan het positief waarderen van iemand of iets uit het verleden. Dit kunnen historische personen zijn, maar ook allegorieën, zoals het Vrijheidsbeeld in New York. Zij hebben gemeen dat zij een positieve waardering uitdrukken. Vandaar dat er geen standbeelden van Anton Mussert zijn, maar wel veel literatuur óver Mussert. Dat bevestigt nog eens dat een historische figuur niet zomaar vergeten wordt als er geen standbeelden zijn.

Standbeelden brengen niet alleen een bepaalde waardering van historische figuren en gebeurtenissen tot uitdrukking. Zij vormen zo'n gevoel ook bij een breder publiek, en het idee dat deze waardering met andere mensen gedeeld wordt, kan voor een gevoel van verbondenheid zorgen. Standbeelden zijn dus een centraal element in processen van groepsvorming: zij maken, om met de woorden van de beroemde historicus en politicoloog Benedict Anderson (2006) te spreken, 'een verbeelde gemeenschap tastbaar'. Of zoals Stuart Hall het uitdrukt: cultureel erfgoed, waar standbeelden een onderdeel van zijn, fungeren als spiegel waarin mensen zich kunnen herkennen (Hall, 2005).

Hier komen nu de twee dimensies van een standbeeld bij elkaar. Aan de ene kant maakt een standbeeld een ver verleden tastbaar en toegankelijk voor mensen in het heden, en aan de andere kant ervaren individuen door deze gedeelde ervaring zichzelf als onderdeel van een groep. De Franse socioloog Émile Durkheim zag dit effect toen hij de clanstructuur van Australische Aboriginals bestudeerde. Hij zag dat de clangemeenschappen vorm kregen in de verering van totems, de heilige dieren die als de voorouders van de clan gezien werden. In deze context waren het geen standbeelden, maar totempalen waarin de gemeenschap zichzelf spiegelde. Standbeelden en totempalen werken volgens hetzelfde principe: een object wordt gezien als de belichaming van een gemeenschappelijke oorsprong. In feite hebben standbeelden en totempalen dezelfde functie: zij verbeelden niet alleen een verleden, zij maken een abstracte groep tastbaar.

De keerzijde van deze medaille is dat totempalen en standbeelden ook de grenzen van zo'n gemeenschap bepalen: wie niet vertegenwoordigd is in het beeld van het verleden, wordt symbolisch buitengesloten. Anders dan in de geschiedwetenschap gaat het hier minder om feiten en een nuchtere beschouwing van het verleden. De kracht van collectieve herinnering is het gladstrijken van ongerijmdheden en tegenstrijdigheden, zodat mensen gevoelsmatig één kunnen worden met de geschiedenis en hun peers.

Ik ben dit artikel begonnen met de vraag naar de rol van beelden in hoe wij kennisnemen van het verleden. Ik heb betoogd dat hierbij verschillende vormen van kennis samenkomen en door elkaar heen lopen. Gezond verstand stelt dat 'wij' niet in beelden geloven. Mensen die zich gekwetst voelen door standbeelden 
maken vanuit dat perspectief geen deel uit van 'onze' beschaving. Maar dit perspectief verhult de bredere kwestie die schuilt in het idee dat het aanstellerij is als mensen zich gekwetst voelen door standbeelden: standbeelden zijn moderne totempalen. Het geloof in beelden is geen kenmerk van 'wildheid', maar juist een belangrijk ingrediënt dat gemeenschap, ook die van de natie, mogelijk maakt (Verrips, 1993). Echte beschaafdheid erkent de kracht van beelden, zowel in positieve als in negatieve zin. Beelden kun je niet zomaar laten staan. Net als de heilige totems moeten zij in toom worden gehouden door krachtige rituelen, anders ontvouwen zij ongetoomd hun kracht.

\section{Literatuur}

Anderson, B. (2006). Imagined Communities: Reflections on the Origin and Spread of Nationalism. Londen/New York: Verso Books.

Bruyneel, K. (2017). Creolizing Collective Memory: Refusing the Settler Memory of the Reconstruction Era. Journal of French and Francophone Philosophy, 25 (2): 36-44.

Hall, S. (2005). Whose Heritage? Un-Settling 'the Heritage', Re-Imagining the Post-Nation. In: J. Littler \& R. Naidoo (red.), The Politics of Heritage: The Legacies of Race. Londen/ New York: Routledge, 23-35.

Port, M. van de, \& Meyer, B. (red.) (2018). Sense and Essence. Politics of Authentication, Aesthetics of Persuasion and the Cultural Production of the Real. New York: Berghahn.

Stengs, I. (2018). Gepopulariseerde Cultuur, Ritueel En Het Maken van Erfgoed. Amsterdam: Vrije Universiteit.

Trouillot, M.-R. (1995). Silencing the Past: Power and the Production of History. Boston, Mass.: Beacon Press.

Verrips, J. (1993). Op Weg Naar Een Antropologie van Het Wilde Westen. Etnofoor, 2: 5-19. 